\title{
The Implementation Of Example Non Example Model With Relay Game On Student Social Skills
}

\author{
$1^{\text {st }}$ Ratna Purwanty \\ Primary School Teacher Education \\ Department, Faculty of Teacher Training \\ and Education \\ Universitas Musamus \\ Merauke, Indonesia \\ ratnapurwanty@unmus.ac.id \\ $4^{\text {th }}$ Markus Palobo \\ Mathematics Education Department, \\ Faculty of Teacher Training and \\ Education \\ Universitas Musamus \\ Merauke, Indonesia \\ markuspalobo@unmus.ac.id
}

\author{
$2^{\text {nd }}$ Agus Kichi Hermansyah \\ Primary School Teacher Education \\ Department, Faculty of Teacher Training \\ and Education \\ Universitas Musamus \\ Merauke, Indonesia \\ Musamus University \\ aguskichi@unmus.ac.id
}

\author{
$3^{\text {rd }}$ Yonarlianto Tembang \\ Primary School Teacher Education \\ Department, Faculty of Teacher Training \\ and Education \\ Universitas Musamus \\ Merauke, Indonesia \\ yonarlianto@unmus.ac.id
}

\begin{abstract}
This study aims to describe the application of the example nonexample model with relay game on social skills in the Social Science (IPS) subject in class IIIA The type of this research was a qualitative descriptive research. This research was carried out on students of class IIIA SDN 2 Merauke in the odd semester of 2018/2019 academic year, with the total of 27 students. The data was collected through observation, interviews, and documentation. The results of this study indicated that (1) the application of the example nonexample model with relay game on the IPS subject by teachers and students was very maximal, this was seen from the enthusiasm and activeness of the students during the learning process; (2) the application of the example nonexample model with relay game on the IPS subject gave a good impact on students' social skills. Students' social skills seem to be increasing when students were invited in asking and answering questions about the pictures displayed by the teacher through power points or posters, in this case, the students actively build ideas and opinions. When students did the relay games and discussed the group assignments, the students worked together, took responsibility, and were willing to accept opinions from their friends in the group. When the students analyzed the result of the work of each group, they mutually build ideas and accepted opinions from friends.
\end{abstract}

Keywords-example nonexample model, relay game, social skill, Lesson Study

\section{INTRODUCTION}

Social Sciences (IPS) lesson which contains social problems requires a solution that involves the active role of students both physically and mentally. According to Susanto, the purpose of social science lesson in elementary schools is to study the situation of the community along with the rules and good habits that apply to the community [1]. Thus, the students are expected to be able to directly experience the existence of interaction that influences the personal and community life. In addition, Sumaatmadja explains that the purpose of social studies lesson is to nurture students to be good citizens, who have the knowledge, skills and social concerns that are useful for themselves, society and country [2]. Thus, the social studies subject learning is expected to develop the of the students' potential to be sensitive to social problems that occur in the community, have a positive attitude and skilled in overcoming any problems that they face in the community.

Social skills are one of the objectives of the Social Sciences (IPS) subjects. Komalasari states that students need to have a good social attitude towards their friends in class because, with a good social attitude, it will facilitate cooperation in groups and ultimately facilitate understanding of learning [3]. In addition, Maftuh states that the IPS subject must play a more important role in developing and strengthening social skills, interpersonal, collaboration, social responsibility, or cross-cultural interactive communication than other subjects [4]. Therefore, it is expected that in the social science subject, the students are able to have competence in the formation of attitudes, behaviors and social skills.

The results of the observation of the learning process in class IIIA SDN 2 Merauke on the Social Sciences (IPS) subject on July 9, 2018 are: (1) when the learning process was conducted with a discussion model, students have not shown 
high social skills yet, they were more likely to be individual; 2) there were many delinquency behaviors committed by students. Some of the students still committed verbal violence against their friends, playing around beyond the normal limits; (3) students were faced with a lack of ability to socialize and cooperate with others; (4) students only chose some friends and did not mingle in class, it was not good for their development and socialization process.

The low social skills of the students can be caused by several factors. According to Dewi et al, the factors used as the indicators that students' social skills are still low are (1) student's sense of responsibility for the tasks assigned by the teacher is still low; (2) students rarely give opinions in the lessons; (3) lack of collaboration between students in working on or understanding the subject matter. Even though the teacher has applied various kinds of learning strategies, students have not yet shown high social skills in following the learning process [5].

According to Sujiono, social skills is an ability to assess what is happening in a social situation, the skills to feel and appropriately interpret the actions and needs of students, the ability to imagine various possible actions and choose one the most appropriate [6]. The students' social skills observed in this study were oral communication skills, cooperative skills, and skills to control a conflict. In addition, Kagan mentions the social skills including (1) building on others ideas; (2) responsibility; (3) working together; and (4) accepting other people's opinions (getting everyone) [7].

Students' social skills can be trained by applying cooperative learning. According to Riyanto, cooperative learning models are learning models designed to teach academic skills as well as social skills including interpersonal skills [8]. Tampubolon explains that cooperative learning is developed from thinking, democratic values, active learning, cooperative behavior and respect for pluralism in a multicultural society [9]. In addition, Jacobsen et al mention that the objectives of cooperative learning include academic learning outcomes, acceptance of diversity and development of social skills. One of the cooperative learning models that can improve social skills is an example non example model [10].

The example non example model can use a media of pictures to help students to learn. Jumanta explains that the example non example model is a model that teaches students to learn to understand and analyze a concept of the media (in the form of pictures) [11]. With pictures, it is expected that the learning and teaching process is more communicative and interesting. Tampubolon states that the example non example model is a model with examples that can come from cases or images that are relevant to the basic competencies [9]. The example non example model can be combined with games that use a media of pictures in its implementation, such as with relay games.
Relay game is a modification game developed from running numbers. This relay game aims to make students improve their social skills. This relay game uses very simple equipment, such as pictures (natural and artificial appearance), picture boxes, Student Worksheets, glue, raffia rope (starting line) and whistles. In here, the picture is used as the media that the runner brings to then be given to the next runner. The picture box is used as the place for the pictures that will be taken by the first runner. Student Worksheet is used to paste the pictures. The raffia rope in this relay game is used as a starting line. Whistle used by the teacher as a sign in this relay game. This relay game is a modification game that aims to make the learning process more enjoyable and improve the students' social skills.

The implementation of the example non example model with relay game is very interesting for students. The steps of the learning activities are: (1) the teacher prepares pictures in accordance with the learning objectives; (2) the teacher displays the pictures; (3) the teacher gives students the opportunity to analyze the pictures; (4) students do relay games: (5) each group is given the opportunity to read the results of the discussion; (5) Starting from the results of the students' discussions, the teacher explains the material in accordance to the objectives to be achieved; (6) draw conclusion [9].

Based on the existing problems and the solutions that are taken, then the research was carried out in the form of Lesson Study through the application of the example non example model with relay games on the social skills in the IPS subject in class IIIA SDN 2 Merauke.

\section{METHODS}

The type of this research was descriptive qualitative research, which has natural settings as a primary data source, descriptive, the process was prioritized rather than results and inductive analysis. This activity was carried out in the form of Lesson Study which included three stages, namely Plan, Do, See. The method used in this study was qualitative. The qualitative method had a research procedure to produce descriptive data in the form of written words and sentences and not using statistical data or numbers about the application of example non example with relay games to students' social skills on the IPS subject in class IIIA of SDN 2 Merauke.

In here, the researchers were the key instruments who were fully participated and the data collectors. Whereas, other instruments are the supporting instruments. This research was conducted in the odd semester of 2018/2019 academic year at SDN 2 which was addressed at Jalan Trikora Merauke. This research was conducted on June 16, 2018. The subject of the research was students of class IIIA SDN 2 Merauke. The number of students in class IIIA was 27 students, consisting of 16 male students and 11 female students. 
The source of data in this study was the activity of teachers and students in the learning process using the example non example model with relay games. Data collection methods in this study were observation, tests, documentation and field notes. The observation was used to collect data related to the activities of students and teachers during the learning activities. Tests were given at the end of the lesson to find out students' learning outcomes. The documentation was carried out to obtain data directly from the location of the research regarding the application of the example non example model with relay games on students' social skills and also as evidence for the learning activities that have been carried out. Field notes were used to find out the problems faced in the learning process.

Social skills indicators used in this study were: (1) building on others ideas; (2) responsibility; (3) working together; and (4) accepting other people's opinions (getting everyone).

\section{RESULTS AND DISCUSSION}

Lesson Study (LS) consists of three stages: plan, do, see. Before the plan, do, see are carried out, researchers and colleagues in one team conducted observations at SDN 2 Merauke. The result of the observation conducted by the researchers are as follows:

Based on the results of the observation on 9 July 2018 in class IIIA of SDN 2 Merauke, the data obtained were: (1) many students experienced difficulties in understanding the concepts of Social Sciences (IPS), one of which was in natural and artificial appearance material; (2) when the learning process was conducted with a discussion model, students have not shown high social skills yet, they were more likely to be individual; (3) many delinquency behaviors were still committed by students. Some of the students still committed verbal violence against their friends, playing around beyond the normal limits; (4) students were faced with a lack of ability to socialize and cooperate with others; (5) students only chose friends and did not mingle in class, it was not good for their development and socialization process. The results of interviews with students also showed that students were less interested to participate in the social science lesson. The learning process in the class was still considered to have a lot of lectures and there were no interesting games. The learning process that students expect was learning that could make them happy and providing a game for them. This showed that the learning process carried out by the teacher was not optimal and has not been in accordance with the expectations of students and learning objectives, especially on the Social Science subject.

One of the efforts carried out by researchers in overcoming these problems, primarily to improve students' social skills in the Social Science subject was that the researchers made learning innovations in the Social Science subject. The innovation made was to create learning that enhances students' social skills through the example non example model with relay games. With this research, it is expected that the teacher can present something different in the learning process, one of which is by using a learning model combined with the game so that students' social skills can be improved. Furthermore, after doing the observation, the researchers carried out the stages of the Lesson Study.

The activities in each stage of Lesson Study in Class IIIA of SDN 2 Merauke are as follows:

The Plan stage was carried out on July 11, 2018. The activities carried out in this planning stage were discussing and reviewing the Learning Implementation Plan (RPP). The discussions in this matter were carried out between researchers and colleagues in a team, school principal, class teachers and heads of the curriculum at SDN 2 Merauke. The discussions were held to: (1) distributing KPL tasks based on Lesson Study (model teachers, observers, and documentaries), (2) preparing observation sheets for teachers' and students' activities, (3) designing Learning Implementation Plans (RPP), (4) discussing the RPP that have been made. At the planning stage, there was a revision of the RPP I made, mainly on the core activities. At first, in the relay game, I wanted that the box containing pictures of natural and artificial appearance was attached to the classroom wall. Some friends suggested, for the efficiency of the place and make the students not confused to the relay games, the boxes should be placed in front of the class so that at the implementation, the students would be more organized.

The Do stage was held on July 16, 2018 at 07.30 Western Indonesian Time to 10.30 Western Indonesian Time. The learning process was carried out by the model teacher observed by the class teacher as the observer. At this stage researchers were the model teachers and carried out a lesson with the students using natural and artificial appearance material. The observer in this study was Ms. Hendrika Walten and Mr. Yonarlianto who worked on documentation. At the time of the implementation, there were four students who did not come to the class IIIA, those were Agustina Arau, Daniel Eskar, Ramma Kirioma and Wihelmina Igimu. The Do stages include the introduction, core and closing activities. The Do stages in the LS activity can be described as follows:

The introduction activity began with inviting students to pray, asking about the students' condition and presence. Then, the teacher did apperception by inviting students to sing a song Dari Sabang Sampai Merauke and dig up information about the song, this was done to link the students' initial knowledge with the material to be studied. After that, the teacher informed the theme and objectives of the lesson that would be studied and it was continued to the core activities.

The core activity began with inviting students to observe pictures of natural and artificial appearance shown by the teacher through power points or posters. Then students and 
teachers were asking and answering questions related to the material. Next, the students were divided into 6 groups. The students paid attention to the instructions for the implementation of group work, related to the implementation of the relay game. For the relay game implementation, each group formed a row, each group member took turns to take one picture from the box provided by the teacher sequentially in accordance with the instructions given by the teacher. Each time they finished taking pictures, students attached the pictures (natural and artificial appearance) on the Student Worksheet that has been provided, after that the next sequence took a picture and so on until the time provided by the teacher. After students did relay games, they discussed the Student Worksheets (LKS 1). Group representatives presented the results of their discussions, then students and teachers discussed the results of the group discussions.

When the teacher displayed pictures of natural and artificial appearance through power points or posters, students were very enthusiastic to follow the lessons. They were active in giving opinions. In this activity, misconceptions have been found, where students mentioned that the dam and the reservoir were the same, then the students mentioned that the plantation was included as a natural appearance. Therefore, in this case, the researcher as a model teacher rectified the misconceptions experienced by these students. For the relay game, students were very active, cooperated with each other, had a responsibility for their assignments and orderly conducted the learning activities. Thus, it could be said that the example non example model with relay game gave a good impact on the students' social skills, both individually and in groups. From the results of the group activities, it was obtained the data that the groups which scored hundreds were three groups, while for the other two groups scored ninety and seventh respectively. For Student Worksheets that were done individually, five students out of twenty-three students scored hundreds. Four students scored ninety, three students scored eighty, seven students scored seventy, two students scored sixty, one student scored fifty, one student scored thirty and one student scored zero. After the core activities, it was continued with closing activities.

The closing activities conducted by the model teacher in learning activities were: guiding students to conclude the learning results, giving assignments to the students to work on Student Worksheets (LKS 2) individually, providing opportunities for students to express their opinions related to the lesson that has been carried out, followed by a closing.

The See stage was done by reflection to study the implementation of learning conducted by the model teacher. At this stage, the model teacher and observer reflected on the results of the observations and documentation of learning activities as a comparison. The results of the observers' observations were: (1) the advantages of the learning process that the model teacher has done were: raising the concepts to the students was good, classroom management was good, made the students active in the learning process, build collaboration between students, trained student to be discipline, optimized the use of facilities and infrastructure in the classroom with pictures, learning became more enjoyable and increased students' self-confidence; whereas (2) for the weakness of the learning process carried out by the model teacher was the distribution of the groups and the implementation of the relay game that was not optimal because the instructions given by the teacher were not clear.

The discussion in this study will present the results of the research of Lesson Study (LS) which is through the application of the example non example model with relay game on the IPS subject in class IIIA of SDN 2 Merauke. The results of the study were the description of the application of the example non example model with relay games to the students' social skills on the IPS subject in class IIIA of SDN 2 Merauke.

Based on the results of the observation and reflection, the results obtained were: the application of the example non example model with the relay game on the IPS subject by the teacher and students was very maximal, this was seen from the enthusiasm and activeness of students during the learning process. In addition, the application of the example non example model with relay game on the IPS subject in Class IIIA gave a good impact on students' social skills. Students' social skills seem to be increasing when students were invited in asking and answering questions about the pictures displayed by the teacher through power point, in this case students actively build ideas and opinions. When students did the relay games and discussed the group assignments, students worked together, took responsibility and were willing to accept opinions from their friends in the group. When students analyzed the result of each group work, they build ideas and accepted opinions from friends.

\section{CONCLUSIONS}

The application of the example non example model with relay games was done through Lesson Study with three stages, namely plan, do, see. From the Lesson Study activity, it showed that the application of the example non example model with the relay game on the IPS subject by the teacher and students was very maximal, this was seen from the enthusiasm and activeness of students during the learning process. In addition, the application of the example non example model with the relay game on the IPS subject gave a good impact on students' social skills. Students' social skills seem to be increasing when students were invited in asking and answering questions about the pictures displayed by the teacher through power points or posters, in this case students actively build ideas and opinions. When students did relay games and discussed the group assignments, students worked together, took responsibility and were willing to accept 
opinions from their friends in the group. When students analyzed the result of each group work, they build ideas and accepted opinions from friends.

\section{ACKNOWLEDGMENT}

We thank Universitas Musamus for facilities and supports. This project was supported by Belmawa Ristekdikti and the publication was supported by Universitas Musamus.

\section{REFERENCES}

A. Susanto, Teori Belajar \& Pembelajaran di Sekolah Dasar. jakarta: Kencana, 2013.

[2] N. Sumaatmadja, Konsep Dasar IPS. jakarta: Pusat Penerbitan Universitas Terbuka, 2007.

[3] K. Komalasari, Pembelajaran Kontekstual Konsep dan Aplikasi. bandung: PT Refika Aditama, 2014.
[4] B. Maftuh, "Memperkuat Peran IPS dalam Membelajarkan Keterampilan Sosial dan Resolusi Konflik," in Pengukuhan Guru Besar dalam Bidang Pendidikan IPS pada FIPIPS UPI, 2010.

[5] A. Dewi, Sari., Sumarmi., Amirudin, "Penerapan Model Pembelajaran Problem Based Learning untuk Meningkatkan Keaktifan dan Keterampilan Sosial Siswa Kelas V SDN Tangkil 01 Wlingi," J. Pendidik. Teor. Penelit. dan Pengemb., vol. 1, no. 3, 2016.

[6] Sugoyono, Metode Penelitian Pendidikan, Pendekatan Kualitatif, dan $R \& D$. Bandung: Alfabeta, 2016.

[7] Kagan, Kagan Cooperative Learning. san clemente: kagan publisher, 2009

[8] Y. Riyanto, Paradigma Baru Pembelajar: Sebagai Referensi Bagi Pendidik dalam Implementasi Pembelajaran yang Efektif dan Berkualitas. jakarta: Kencana Prenada Media Group, 2010.

[9] S. Tampubolon, Penelitian Tindakan Kelas Sebagai Pengembangan Profesi Pendidik dan Keilmuan. Jakarta: Erlangga, 2014

[10] D. A. Jacobsen and D. Eggen, Paul Kauchak, Metode-metode pengajaran. jakarta: pustaka pelajar, 2009.

[11] H. Jumanta, Model dan Metode Pembelajaran Kreatif dan Berkarakter. bogor: ghalia, 2014. 